\title{
Crossed Random-Effect Modeling: Examining the Effects of Teacher Experience and Rubric Use in Performance \\ Assessments
}

\author{
Adnan KAN**
}

Okan BULUT ${ }^{* * *}$

\section{Suggested Citation:}

Kan, A., \& Bulut, O. (2014). Crossed random-effect modeling: examining the effects of teacher experience and rubric use in performance assessments. Eurasian Journal of Educational Research, 57, 1-28. doi: dx.doi.org/10.14689/ejer.2014.57.4

\begin{abstract}
Problem Statement: Performance assessments have emerged as an alternative method to measure what a student knows and can do. One of the shortcomings of performance assessments is the subjectivity and inconsistency of raters in scoring. A common criticism of performance assessments is the subjective nature of scoring procedures. The effectiveness of the performance assessment procedure depends highly on the quality and coordination of teacher and rubric. To gain a better understanding of the interaction between teachers and performance assessments, it is crucial to examine the effects of teacher-related factors and how teachers interact with scoring rubrics when grading performance assessments. One of these factors is teachers' work and scoring experience. When grading performance assessments, the experienced teachers may be expected to grade student performances more objectively through their experience in instruction and evaluation than the teachers with less teaching and scoring experience.

Purpose of Study: This study investigates the impact of rubric use and teaching experience on teachers' scoring behaviors in performance assessments. The effects of teaching experience and rubric use on the consistency of scores assigned by teachers is examined through an empirical study.
\end{abstract}

*Corresponding author: Dr., Department of Education Sciences, Gazi University, Ankara, Turkey. E-mail: adnankan@gazi.edu.tr

*** Dr., Department of Educational Psychology, University of Alberta, Edmonton, Alberta, Canada. E-mail: bulut@ualberta.ca 
Methods: Crossed random-effects modeling was used to estimate rater effects, consistency among the teachers, and the effect of teaching experience.

Findings and Results: Results indicated that lack of a scoring guide may cause the teachers to establish their performance criteria and score tasks inconsistently. When teachers used a rubric, inter-rater reliability substantially increased. Experienced teachers and teachers with little teaching experience exhibited different severity patterns in scoring.

Conclusions and Recommendations: Based upon the results of this study, it appears that teachers who have more teaching experience tend to score performance tasks more leniently than teachers who do not have long years of teaching experience. The differences in the teachers' scoring due to their teaching experience became negligible when all teachers used a scoring rubric. In addition to teaching experience, the potential effects of other external factors should also be considered to make the use of rubrics more effective in performance assessments. This study illustrated an alternative methodology to estimate variance components and the effects of fixed factors within the same analysis. A big advantage of this modeling approach over generalizability theory is that it allows for the separation of random and fixed effects from each other. Although the findings of this study enrich the limited knowledge about the effects of rubric use and teaching experience on teachers' scoring behaviors, further research is needed to understand the reasons why these factors are influential.

Keywords: Performance assessment, rubric, teaching experience, reliability, rater effects, crossed random effects model.

In the last two decades, most educators in $\mathrm{K}-12$ and higher education institutions have started focusing on critical thinking and problem solving abilities rather than factual knowledge and lower-level cognitive skills. To prioritize critical thinking and problem solving skills in instruction, the evaluation policies and procedures have also been changing from the conventional testing of knowledge to -evaluation for learning\| (Dochy, Gijbels, \& Segers, 2006). To measure critical thinking, traditional methods of assessment (e.g., paper and pencil assessments, multiple-choice tests) do not seem to be adequate. Standardized test scores and traditional ways of reporting grades provide a narrow and arbitrary measuring system that does not give any additional information about instructional purposes (Routman, 1991). Therefore, the inadequacy of the existing assessment methods has led to the development of alternative testing methods-such as performance assessments-that prompt students to use higher-order thinking skills such as analysis, synthesis, and evaluation.

Although standardized tests have dominated student assessment systems and assessment policies such as No Child Left Behind for years, educators in the United States and other nations have been able to move to utilizing performance 
assessments and portfolios as an alternative against standardized testing for assessing student performances. The essence of reality in an assessment is to provide more valid information about the competence of the student and to reflect complexity in the real world rather than solely focusing on the truth where the context is the only source for the learning process (Darling-Hammond \& Synder, 2000). As Palm (2008) mentioned, the performance assessment method is viewed as providing more opportunities to measure complex skills and communication, which are considered important competencies and disciplinary knowledge needed in today's society. In comparison to conventional assessment methods, performance assessments allow students to become more open in their responses (Messick, 1996). On such assessments, students are required to perform a task rather than select an answer from a ready-made list, such as multiple-choice items. As a result, performance assessments are able to take control of more elusive part of learning in such a way that students are required to deal with realistic and authentic problems.

Despite their many advantages over traditional assessment methods, performance assessments have not been considered as the main tool for student assessment. A common criticism of performance assessments is the subjective nature of scoring procedures. While questions in traditional assessments can easily be scored as right or wrong, the difference is not as clear-cut with performance assessments (Brualdi, 1998). Two important steps are required to minimize the role of subjectivity in performance assessments. First, a scoring mechanism should be developed to grade performance assessments in a reliable way. This scoring mechanism should consist of performance level descriptors (PLDs) that provide information to teachers and students about the skill and knowledge a student needs to demonstrate along with a scoring rubric that indicates what criteria should be used to evaluate students' performances. The second step is to provide training to teachers or raters about how to use PLDs and rubrics to make judgments about students' performance on a task.

The effectiveness of the performance assessment procedure highly depends on the quality and coordination of teacher and rubric. To have a better understanding of the interaction between teachers and rubrics, potential factors that may influence scoring procedures should be carefully examined. One of these factors is teachers' work and scoring experience. Experienced teachers may be expected to grade students' performances more objectively because of their experience in instruction and evaluation. Of course, this does not necessarily mean that teachers with little experience would score inconsistently. Rather, teachers who have recently started their careers can be more objective and consistent in scoring performance assessments since performance-based assessment systems have recently been a core part of teacher education programs. To gain a better understanding of the interaction between teachers and performance assessments, it is crucial to examine the effects of teacher-related factors (e.g., teaching experience) and how teachers interact with scoring rubrics when grading performance assessments. This study investigates the impact of teaching experience and rubric use on teachers' scoring behaviors in 
performance assessments. The effects of teaching experience and rubric use on the consistency of scores assigned by teachers is examined through an empirical study.

\section{Rubrics in Performance Assessments}

Performance assessments require grading strategies that are commonly used in the applied sciences, performing arts, fine arts, and Olympic competitions. For example, in the context of the science laboratory, students are graded based on their performance of manipulating variables, using scientific apparatus, identifying hypotheses, making measurements and calculations, organizing and managing data, and the communication of results (Slater \& Ryan, 1993). Studies that have closely looked at performance assessments indicate that, if the evaluation criteria are clear and there are available examples to show levels of competency, performance assessments are highly consistent across different raters (Kulm \& Malcom, 1991; O'Neil, 1992). To assure that raters implement a consistent grading procedure across all examinees, scoring guidelines called -rubrics\| are used for scoring performance assessments.

Rubrics are the vehicles that provide a useful mechanism to translate students' achievement into assessments (Schafer, Swanson, Bené, \& Newberry, 2001). Rubrics provide a description of various levels of performance for a certain task, and define what varying levels of mastery should look like (Hafner \& Hafner, 2003). To produce valid and reliable results, a rubric should provide enough information to help raters to assess student performances (Stuhlmann, Daniel, Dellinger, Denny, \& Powers, 1999). Rubrics usually consist of a scoring scale from 3 to 5 points depending on the evaluation criteria. Each of the points corresponds to a certain level of performance on a particular task (Wiener \& Cohen, 1997). The scoring criteria on the rubric must correspond with the pre-specified standards, and distinguish between levels of performance (Farr \& Tone, 1998).

Previous research has indicated that when raters use rating scales or rubrics inconsistently, it may result in a wide range of misleading scores (Hadden, 1991; Wigglesworth, 1994). Inconsistent use of rubrics may occur due to a lack of understanding of the construct or the rubric. Raters may attempt to use wide range of non-criterion information when scoring performances (Ang-Aw \& Goh, 2011). In classrooms, teachers can easily familiarize themselves with scoring rubrics because they are supposed to know the construct to be measured and performance levels to be achieved. However, it does not guarantee that each teacher comprehends a rubric in the same way. As teachers become more competent and experienced with instructional practices, they can use scoring rubrics and performance assessments more effectively in their classrooms.

The teacher's role in assessments is crucial because they make judgments about the quality of a student's performance. Brennan (2000) contends that, in most performance assessments, raters do not often cause a considerable variability in observed scores. However, this does not necessarily mean that this variability is always negligible, and so it should be ignored. Differentiation among raters' scoring behaviors may be an important source of score variation because raters' scoring 
behaviors have a direct impact on the reliability and validity of performance assessments. There are several factors that may affect raters' scoring performances, such as rater training, rubric use, quality of rubrics, and multiple scoring occasions. In addition, teacher characteristics such as teaching background, teaching experience, and scoring experience may also influence the way teachers approach the scoring of performance assessments.

Receiving decent training on how to score performance tasks using a rubric may positively influence the way that raters understand and score tasks in an assessment (Schafer et al., 2001; Stuhlmann et al., 1999). Of course, training raters does not necessarily assure that all raters interact with the scoring rubric and the assessment in the same way. Despite receiving the same training about scoring rubrics, raters may evaluate student performances differently because of their own construct of a good performance (Lumley, 1998; Schafer et al., 2001). As Eckes (2008) highlighted, raters may differ not only in the way they understand and apply the scoring criteria, but also in the level of subjectivity they incorporate into scoring, and in the degree to which their ratings are consistent across examinees, scoring criteria, and tasks. Even though teachers use the same rubric, they may differ in terms of their scoring severity based upon their familiarity with rubrics and performance assessments.

Factors such as the background and scoring experience of the raters have also been shown to affect raters' scoring practices (Eckes, 2008; Hamp-Lyons, 1991). In addition to scoring experience, the teaching experience of teachers is also an important criterion that has been used by many countries (e.g., England, France, and Canada) to recruit raters who score the nation-wide exams. Teaching experience as a rater selection criterion has frequently become embedded in the cultural expectations associated with the tests (Royal-Dawson \& Baird, 2009). For instance, in the UK, the Assessment and Qualifications Alliance (AQA) requires raters selected for national examinations to have suitable academic qualifications, and at least three terms of teaching experience that should be recent and relevant.

Although teaching experience has been a criterion for rater selection, there is very little research about the effect of teaching experience on scoring and how to select raters who can score more accurately (e.g. Pinot de Moira, 2003; Royal-Dawson \& Baird, 2009). Since performance and portfolio assessments are relatively newer techniques in comparison to conventional testing, new teachers may be expected to be more familiar with performance assessments and rubrics for scoring portfolios and performance tasks. However, experienced teachers are also advantageous because they are more likely to have a better sense of assigning coherent scores across examinees based upon their experience. Previous research suggests that raters with little experience tend to score tasks more severely than experienced raters (Shohamy, Gordon, \& Kraemer, 1992; Weigle, 1999). However, Myford and Mislevy (1994) and Meyer (2000) found that teaching experience had only a negligible impact on predictions of rater severity.

These rater-related issues bring us to the question of whether severity in scoring or inconsistency among raters is more noteworthy. Since performance and portfolio 
assessments in classrooms are mostly graded by a single teacher, the issue of inconsistency among raters is not likely to occur. In that case, exposing all of the students' responses to the bias of a single rater, which is known as rater severity, is a more serious issue. However, in large-scale testing programs, the main concern is often inconsistency rather than severity in scoring. Variations across raters in scoring severity can be accounted for by adjusting candidates' scores (Baird \& Mac, 1999). To examine the consistency among raters or across scoring occasions, different measures of consistency such as inter-rater and intra-rater reliability coefficients can be used.

Reliability of Performance Assessments

Raters, tasks, and other sources of score variation can influence the precision of performance assessments (Brennan, 2000). Each source brings different types of issues that may influence the consistency of scoring within or between raters. There are several methods to determine consistency of scores across raters or occasions, such as Cohen's kappa statistic (Cohen, 1960), Pearson correlation coefficient, and coefficient alpha (Crocker \& Algina, 1986). All of these reliability coefficients have been used to examine a single source of measurement error in students' scores. An alternative way to examine the consistency of scores is to obtain measurement estimates based on a summary score for each participant, taking into account the extent to which each judge influences the score. The most common example of this method is generalizability theory, which allows for estimating reliability by examining multiple sources of errors and their possible interactions simultaneously (Brennan, 2001; Shavelson \& Webb, 1991).

Unlike a single error term in classical test theory (CTT) that is the total variation in scores due to error, generalizability $(G)$ theory allows for the examination of multiple sources of error simultaneously (Shavelson \& Webb, 1991). G theory extends the idea of total variation consisting of true score and error variations in CTT by ascribing variations in observations to specific sources, such as persons, raters, tasks, etc. In $G$ theory, sources of random variation are defined as facets. A generalizability model can separate out random variations due to each facet that contribute to the total error variation. Detecting the variation due to each facet can provide a mechanism for optimizing the reliability of performance assessments.

In generalizability studies, participants, tasks, and raters are either nested or crossed. Crossed designs are those where every condition of each facet is repeated for every condition of the other facets (e.g., each rater grades all tasks responded to by all persons). Differences in rater severity are taken into account at the level of the individual person, facets, or group (Stemler, 2004). For a study with three crossed random facets (e.g., person $x$ rater $x$ task), random variation due to each of these facets, and their two-way and three-way interactions, are estimated. In this example, the total observed score variance $\left(X_{\text {prt }}\right)$ is decomposed into seven variance components:

$$
\sigma^{2}\left(X_{p r t}\right)=\sigma_{p}^{2}+\sigma_{r}^{2}+\sigma_{t}^{2}+\sigma_{p r}^{2}+\sigma_{p t}^{2}+\sigma_{r t}^{2}+\sigma_{p r t}^{2}
$$


Variance components are used to compute a generalizability coefficient that is the ratio of score variance to the sum of score variance and residual variance. The generalizability coefficient is analogous to the reliability coefficient in CTT (Brennan, 2000; Shavelson \& Webb, 2005). As intraclass correlation coefficients, the generalizability coefficient can be computed by dividing the score variance among persons by the sum of score variance and error variance. In a crossed person-by-item design, the generalizability coefficient can be shown as follows:

$$
E \rho^{2}=\frac{\sigma^{2}(\mathrm{p})}{\sigma^{2}(\mathrm{p})+\sigma^{2}(\delta)}
$$

where $\sigma^{2}(p)$ is universe score variance or true score variance and $\sigma^{2}(\delta)$ is the relative error vaiance of the scores, which is basically the sum of $\sigma^{2}(p t), \sigma^{2}(p r)$, and $\sigma^{2}(p r t)$. The relative error variance in $G$ theory corresponds to residual or error variance in CTT. As with most reliability indices, the larger $E \rho^{2}$, the higher reliability the scores have.

Although $G$ theory is able to break down different sources of error variation, it does not allow for the estimation of fixed covariates (i.e., fixed effects) in addition to error variation (i.e., random effects). A more sophisticated approach, mixed-effects modeling, can overcome this limitation by estimating random and fixed effects together and allowing additional covariates to be included in the model.

\section{Random-Effects Modeling}

$G$ theory is accepted as the equivalent of the random effects model of the analysis of variance (ANOVA). The variability in scores is examined rather than estimation of universe scores because the facets are assumed to be randomly selected from some relevant universe, as in random-effects ANOVA (Ward, 1986). Facets in the generalizability model are defined as random effects in the random-effects ANOVA model. Mixed-effects modeling is a general framework that combines both linear regression and random effects modeling. Mixed-effects models are primarily used to describe linear or non-linear relationships between a dependent variable and some covariates in data that are grouped according to one or more classification factors (Pinheiro \& Bates, 2000, p. 57).

Random effects in mixed-effect models correspond to facets in G theory. Random variation due to the facets and their interactions are captured by estimating random effects. Unlike hierarchical or multilevel models in which random effects must be assumed to be nested, mixed effects models allow random effects to be crossed. Because all facets are crossed with each other, this model can be called a crossed random-effects model. A crossed random-effects model with three crossed facets (e.g., persons, tasks, and raters) can be shown as follows:

$$
Y_{j i k}=X_{j i k} \beta+T_{i} t_{i}+P_{j} p_{j}+R_{k} r_{k}+\varepsilon_{j i k}
$$


In Equation 3, $Y_{j i k}$ is the score of person $j$ on task $i$ determined by rater $k$, and $\beta$ is the fixed-effect coefficient that is an identical intercept term for all the facets in the model. The next term, $\boldsymbol{X}_{j i k}$, is a design matrix that includes the fixed-effect regressors for person $j$ on task $i$ graded by rater $k$. Similar to $\boldsymbol{X}_{j i k}, \boldsymbol{T}_{i}, \boldsymbol{P}_{j}$, and $\boldsymbol{R}_{k}$ are the design matrices that represent the random-effect regressors for persons, tasks, and raters. The multiplicators of the design matrices are the random-effect coefficients for persons, tasks, and raters. These random effects are assumed to have a multivariate normal distribution, $t_{i}, p_{j}, r_{k} \sim N\left(0, \sigma^{2} \Sigma\right)$, which allows reach random effect to vary by its group. These terms are thought of as random variables rather than as parameters. Therefore, they are similar in this respect to the errors (Fox, 2002). The last term in the equation, $\varepsilon_{j i k}$, is the error term for the score of person $j$ on task $i$ given by rater $k$. The error terms are also assumed to be multivariately normally distributed, $\varepsilon_{j i k} \sim N(0$, $\left.\sigma^{2} I\right)$. The error term, $\varepsilon_{j i k}$, in the crossed random-effects model corresponds to the three-way interaction, $\sigma^{2}$ (prt), in $G$ theory.

Two-way and three-way interactions of persons, tasks, and raters can be used as sources of random variation in the crossed random-effects model. For instance, the interaction between tasks and raters (i.e. TxR) can be included in the model as a random effect to explain the random variation in the scores due to this interaction. It should also be noted that Equation 1 does not include any predictors (i.e. fixed effects) in the model. As described earlier, a crossed random-effects model can simultaneously estimate fixed effects and crossed random effects. Assuming there are fixed effects to be estimated in the model, Equation 3 can be rewritten in a short form as:

$$
Y_{i j k}=X_{j i k} \beta+Z_{j i k} b+\varepsilon_{j i k}
$$

where $\boldsymbol{\beta}$ includes all fixed-effect coefficients and $\boldsymbol{b}$ includes all random-effect coefficients in the model. The design matrices for fixed and random effects are represented by $\boldsymbol{X}_{j i k}$ and $\boldsymbol{Z}_{j i k}$, and $\varepsilon_{j i k}$ is the vector of residual error of the scores across all facets.

In a crossed random-effects model, additional predictors that denote fixed effects can be either continuous or categorical. If the predictor is categorical, one of its categories becomes the reference group as a result of the dummy coding scheme. In the context of performance assessments, the joint analysis of random and fixed effects allows testing whether persons, tasks, raters, and the interactions of these components contribute to scores independently. Furthermore, the impact of predictors that are not expected to vary randomly (i.e. fixed effects) can be tested. Models with different random and fixed effects can be compared based on log likelihood and deviance statistics (Raudenbush \& Bryk 2002, p. 60-61).

\section{Interrater and Intrarater Reliability}

As explained earlier, variances of random facets can be used to compute a reliability coefficient that is the proportion of true score variation to the observed 
score variation. This type of reliability coefficient indicates the extent which a given assessment measures persons' true scores. Other reliability coefficients can also be computed to examine how raters influence the variability in persons' observed scores. Depending on the design of the study, two types of reliability coefficient can be used. These are inter-rater and intra-rater reliability coefficients. When multiple raters grade students' responses to the same task or different tasks, the correlation between the scores assigned by the raters becomes an indicator of inter-rater reliability (Brennan, 2003). The inter-rater reliability coefficient shows the consistency of measurements across raters and the extent to which the raters are interchangeable (Eliasziw, Young, Woodbury, \& Fryday-Field, 1994). In a person $\mathrm{x}$ task $\mathrm{x}$ rater (i.e., $p$ $\mathrm{x} t \mathrm{x} r$ ) design, the inter-rater reliability coefficient for a single occasion is:

$$
\rho_{\text {interrater }}^{2}=\frac{\sigma^{2}(\mathrm{p})+\sigma^{2}(\mathrm{pt})}{\sigma^{2}(\mathrm{p})+\sigma^{2}(\mathrm{pt})+\sigma^{2}(\mathrm{pr})+\sigma^{2}(\mathrm{ptr})} .
$$

When Equation 5 is reorganized using the notation in crossed random-effects modeling (see Equation 3), it can be written as:

$$
\rho_{\text {interrater }}^{2}=\frac{p_{j}+p t_{j i}}{p_{j}+p t_{j i}+p r_{j k}+\varepsilon_{j i k}}
$$

Inter-rater reliability is useful for measurements that are carried out on a single occasion. When raters grade items on multiple occasions, a rater's consistency (assigning the same or similar scores across occasions $\left(\mathrm{o}_{\mathrm{m}}=1, \ldots ., M\right)$ can be checked by using an intra-rater reliability coefficient. For a single item in a person $\mathrm{x}$ rater $\mathrm{x}$ occasion design, intra-rater reliability can be defined as:

$$
\rho_{\text {int rarater }}^{2}=\frac{\sigma^{2}(\mathrm{p})+\sigma^{2}(\mathrm{pr})}{\sigma^{2}(\mathrm{p})+\sigma^{2}(\mathrm{pr})+\sigma^{2}(\mathrm{po})+\sigma^{2}(\mathrm{pro})} .
$$

Equation 7 can also be written again using random-effect components from the crossed random-effects model as follows:

$$
\rho_{\mathrm{int} \mathrm{rarater}}^{2}=\frac{p_{j}+p r_{j k}}{p_{j}+p r_{j k}+p o_{j m}+\varepsilon_{j m k}}
$$

The intra-rater reliability coefficient can be computed for each item separately by averaging the scores from each task over raters. As Brennan (2003) suggested, additional complexities may arise when interpreting these reliability coefficients because it may be difficult to determine whether a facet should be defined as random 
or fixed in the study. Yet, they can still be very informative when researchers try to assure that raters are functioning as expected.

\section{Method}

\section{Research Design}

The aim of this study is to examine the effects of teaching experience and rubric use on teachers' grading behaviors across different occasions in a performance assessment. A performance task was given to the eighth-grade students, and their responses were graded by 17 teachers with and without a rubric. A crossed randomeffects modeling approach was used to examine the individual contributions of students, tasks, teachers, and the interactions of these components with the variations in students' scores. In addition, rubric use, teachers' work experience, and the duration between grading periods are used as fixed-effects in the model. Two research questions addressed in this study are: 1) How does the rubric use influence the scoring of performance assessments? 2) Is there any interaction between teachers' work experience and their grading behaviors? The following sections describe the sample, data collection procedure, and statistical techniques used for data analysis.

\section{Participants and Data Collection}

The participants of this study were 50 eighth-grade students and 17 math teachers. The sample of teachers was chosen to represent a wide range of experience. Years of experience as a teacher ranged from one year to 26 years in the sample. Students, teachers, and performance tasks were fully crossed facets. All students in the sample responded to the same questions in a performance assessment. The responses of all the students were graded by each of the seventeen teachers.

The content of the performance assessment in this study was graphical comprehension in mathematics. In the literature, researchers have focused on the three sublevels of graph comprehension (Friel, Bright, \& Curcio, 2001; Wainer, 1992). These sublevels are translation, interpretation, and extrapolation/interpolation. Translation represents a change in the form of a communication (Friel et al., 2001). Translation occurs when one interprets a graph at a descriptive level and comments on the structure of the graph (Jolliffe, 1991; Wood, 1968). Interpretation means organizing the information in the graph and determining which information is more important or necessary (Wood, 1968). Interpretation happens when one looks for relationships among specifiers in a graph or between a specifier and a labeled axis (Friel et al., 2001). Extrapolation/interpolation means understanding the data in a graph and making inferences or conclusions. Extrapolation and interpolation occur when one extrapolates or interpolates by perceiving trends shown in graphical data or by specifying implications (Wood, 1968).

By using the three sublevels of graphical comprehension, a performance assessment task was developed by the researchers along with the math teachers to assess students' graphical interpretation skills. The assessment consisted of four 
open-ended questions that measure the understanding and interpretation of graphical representations of mathematical data. The first two questions included bar charts, and the other two questions were based on line charts. The first bar and line chart questions focused on the relationship between two facts for a single variable (e.g. distance by time for a bike) whereas the charts in the second bar and line chart items were about the relationship between two facts for two separate variables (e.g. phone bills by month for home and cell phones). Figure 1 shows an example of these items. All of the items required students to understand the graphical representation and create a story based on their interpretation of the graph. Students' graphical interpretation skills were evaluated based on how they interpreted the data in the graph, made conclusions, and related the information within a story.

After the students completed the performance assessment, each of the 17 teachers was asked to grade students' responses to the four questions. All questions carried an equal value in scoring. Each question was worth twenty-five points. The teachers graded the questions on four occasions. First, the teachers were asked to grade students' responses based on their own scoring criteria without a scoring rubric. Three weeks after the first grading occasion, the teachers graded the questions again, but this time they were given an analytic rubric based on the performance criteria determined for this assessment. An analytic rubric (see Appendix) was preferred because extra details in the analytic rubric were anticipated to help teachers to follow the same performance criteria.
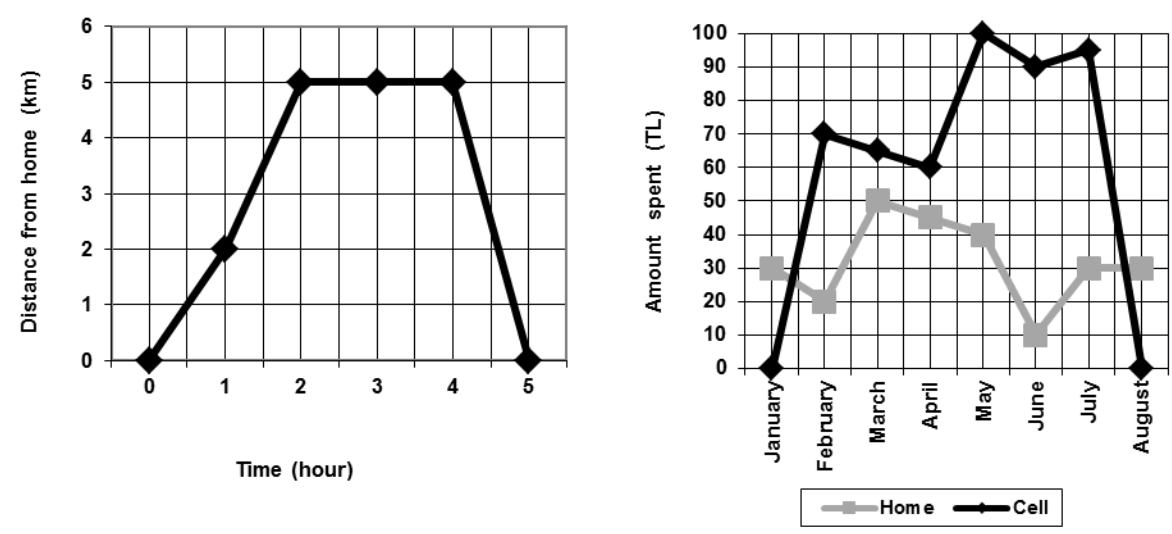

Figure 1. Example questions with line graphs for a single variable (left) and two separate variables (right) in the performance assessment.

To examine the effect of time on the consistency of raters' scores, the third occasion took place ten weeks after the second occasion. As in the first occasion, the teachers graded students' responses without using a rubric. The last grading occasion was three weeks after the third occasion. The teachers scored the questions by using the same scoring rubric that they used on the second scoring occasion. To 
prevent the teachers from remembering students' responses from previous scoring occasions, the order of the students' answer sheets were scrambled, and different identification numbers were assigned to the students for each occasion.

\section{Data Analysis}

The design of this study consisted of three random facets that were fully crossed with each other. These facets were persons, tasks (i.e. questions), and raters (i.e. teachers). In addition to these facets, occasion was another source of variation, which was crossed with tasks and raters. The impact of these sources of variation on students' scores was examined using crossed random-effects models. All facets and their interactions were treated as random effects in the models. In addition to the random effects, there were two predictors that were used as fixed effects. These predictors were teachers' work experience and rubric use. Work experience (ranging from 1 to 26) represents how many years a teacher has served in a school. This was self-reported information provided by the participating teachers of the study. Rubric use was a categorical variable. Occasions in which the teachers used a scoring rubric were coded as one, and other occasions without rubric use were coded as zero.

Four crossed random-effects models were used to address the research questions explained earlier. The first two models aimed to identify variations in the scores due to the raters within occasions and across occasions. Model 1 was based on a $p \times t \times r$ design, which included random effects for persons, raters, tasks, and their two-way interactions. Model 1 was run for each occasion separately, and the inter-rater reliability coefficient was computed for each occasion by using Equation 6. Model 2 used a $p \times r \times o$ design. It estimates random effects for persons, raters, occasions, and their interactions. Model 2 was run for each task separately, and intra-rater reliability coefficients were computed. When intra-rater reliability coefficients were computed, the person $x$ occasion interaction was not included because the same responses from the students were graded by the raters across four occasions, and so there was no interaction between students and occasions.

Model 3 was an overall model that treated all of the facets and their interactions (i.e., persons, tasks, and occasions) as random effects. Because students' responses to the questions were fixed across occasions, the interaction between students and occasions was not included in the model. The last model, Model 4, estimated fixed effects for teachers' work experience and rubric use in addition to all random effects in Model 3. The purpose of this model was to estimate the effects of rubric use and work experience on teachers' grading behaviors after accounting for the effects of all facets.

All of the models were estimated using the lme4 package (Bates, Maechler, \& Bolker, 2011) in $\mathrm{R}$ ( $\mathrm{R}$ development core team, 2012). The lme4 package can estimate mixed-effects models with a fast algorithm for parameter estimation (see Bates, 2005; West, Welch, \& Gałlechki, 2007). The lme4 package requires a long data format (i.e. multiple rows for each person). The data structure is presented in Table 1. 


\section{Table 1}

Structure of the Facets in the Data.

\begin{tabular}{ccccccc}
\hline Student & Question & Score & Teacher & Experience & Occasion & Rubric \\
\hline 1 & 1 & 15 & 1 & 5 & 1 & 0 \\
1 & 2 & 25 & 1 & 5 & 1 & 0 \\
1 & 3 & 20 & 1 & 5 & 1 & 0 \\
1 & 4 & 15 & 1 & 5 & 1 & 0 \\
1 & 1 & 10 & 1 & 5 & 2 & 1 \\
1 & 2 & 11 & 1 & 5 & 2 & 1 \\
1 & 3 & 8 & 1 & 5 & 2 & 1 \\
1 & 4 & 11 & 1 & 5 & 2 & 1 \\
1 & 1 & 20 & 1 & 5 & 3 & 0 \\
1 & 2 & 20 & 1 & 5 & 3 & 0 \\
1 & 3 & 20 & 1 & 5 & 3 & 0 \\
1 & 4 & 20 & 1 & 5 & 3 & 0 \\
1 & 1 & 13 & 1 & 5 & 4 & 1 \\
1 & 2 & 12 & 1 & 5 & 4 & 1 \\
1 & 3 & 9 & 1 & 5 & 4 & 1 \\
1 & 4 & 11 & 1 & 5 & 4 & 1 \\
\hline
\end{tabular}

Note: Only scores of student 1 given by teacher 1 is shown here.

\section{Results}

Table 2 shows that the $p \times t \times r$ design (Model 1) estimated seven variance components associated with persons, tasks, raters, person-by-task interaction, person-by-rater interaction, task-by-rater interaction, and person-by-task-by-rater interaction. The $p \times t \times r$ design was estimated separately for each of the four scoring occasions. In the first and third occasions, the largest variance component was attributable to student-by-task-by-rater interaction and students, respectively. The largest variance component was attributable to student-by-task interaction on the second and fourth occasions, accounting for more than $25 \%$ of total score variance. This was a desirable result because it indicates that most score variability was explained by the differences in students' graphical comprehension abilities rather than the raters.

A slight difference was found between the occasions in terms of inter-rater reliability estimates. Inter-rater reliability was fairly higher when the teachers were given a scoring rubric for the second and fourth occasion. This means that the scores assigned by the teachers exhibited better consistency when they were given a scoring rubric. Also, the amount of total variance decreased by as much as $70 \%$ when a scoring rubric was used for grading. The proportions of person-by-rater and raterby-task interactions to the total variance were almost the same across four occasions, although the actual amount of these interactions was much smaller on the second and last occasions. This suggests that measurement errors due to the rater facet were reduced when a scoring guide was introduced to the raters. 


\section{Table 2}

Estimated Random Effects and Inter-rater Reliability Coefficients in Model 1 Across Four Occasions.

\begin{tabular}{|c|c|c|c|c|c|c|c|c|}
\hline \multirow{2}{*}{ Facet } & \multicolumn{2}{|c|}{ Occasion 1} & \multicolumn{2}{|c|}{ Occasion 2} & \multicolumn{2}{|c|}{ Occasion 3} & \multicolumn{2}{|c|}{ Occasion 4} \\
\hline & $b$ & $\%$ & $b$ & $\%$ & $b$ & $\%$ & $b$ & $\%$ \\
\hline $\mathrm{p}$ & 13.65 & 24 & 3.55 & 23 & 13.73 & 27 & 3.47 & 18 \\
\hline $\mathrm{t}$ & 1.56 & 3 & 0.28 & 2 & 1.64 & 3 & 0.49 & 3 \\
\hline $\mathrm{r}$ & 4.19 & 7 & 2.21 & 14 & 5.26 & 10 & 3.43 & 20 \\
\hline$p \times t$ & 14.55 & 25 & 4.76 & 31 & 13.69 & 27 & 4.61 & 27 \\
\hline$p \times r$ & 3.86 & 7 & 0.76 & 5 & 3.72 & 7 & 0.91 & 5 \\
\hline$r \times t$ & 1.24 & 2 & 0.39 & 3 & 0.99 & 2 & 0.47 & 3 \\
\hline$p \times t \times r$ & 18.51 & 32 & 3.57 & 23 & 14.72 & 25 & 3.52 & 23 \\
\hline$\rho^{2}$ & \multicolumn{2}{|c|}{.56} & \multicolumn{2}{|c|}{.66} & \multicolumn{2}{|c|}{.59} & \multicolumn{2}{|c|}{.65} \\
\hline
\end{tabular}

Note: p: person; t: question; r: rater. $\rho^{2}=$ Inter-rater reliability; $b=$ estimated random effect; $\%=$ Percent of total variability.

Table 3 shows the results from the $p \times r \times o$ design (Model 2), which estimated six variance components. As explained earlier, this model was run for each question separately to compute intra-rater reliability across four occasions. The results indicated that the largest variance component was attributable to students in all four questions. Person-by-rater-by-occasion interaction was the second largest source of the variation within the questions. The highest variation $(52 \%)$ in the scores due to the students was observed in the last question (question 4). This question also exhibited the highest intra-rater reliability. The rater effect was similar across the four questions. This indicates that teachers' severity or leniency in scoring followed a similar pattern across the questions.

On the second and last occasions, where the teachers used a scoring rubric, the mean scores for the questions became smaller (see Figure 2). This suggests that teachers tend to score more severely when they use a rubric for scoring the performance assessment items. In addition to the shrinkage in the mean scores, the questions showed fewer scoring errors when the teachers used a scoring rubric on the second and last occasions. 


\section{Table 3}

Estimated Random Effects and Intrarater Reliability Coefficients in Model 2 Across Four Questions.

\begin{tabular}{|c|c|c|c|c|c|c|c|c|}
\hline \multirow{2}{*}{ Facet } & \multicolumn{2}{|c|}{ Question 1} & \multicolumn{2}{|c|}{ Question 2} & \multicolumn{2}{|c|}{ Question 3} & \multicolumn{2}{|c|}{ Question 4} \\
\hline & $b$ & $\%$ & $b$ & $\%$ & $b$ & $\%$ & $b$ & $\%$ \\
\hline$p$ & 11.59 & 33 & 14.11 & 41 & 16.49 & 39 & 22.28 & 52 \\
\hline $\mathrm{r}$ & 1.25 & 3 & 2.01 & 6 & 2.87 & 7 & 2.36 & 6 \\
\hline $\mathrm{o}$ & 5.82 & 16 & 3.71 & 11 & 5.69 & 13 & 2.42 & 6 \\
\hline $\mathrm{p} \times \mathrm{r}$ & 2.91 & 8 & 1.33 & 4 & 1.63 & 4 & 2.34 & 5 \\
\hline $\mathrm{r} \times \mathrm{o}$ & 1.68 & 5 & 2.59 & 7 & 3.34 & 8 & 1.93 & 5 \\
\hline $\begin{array}{l}p \times r \times \\
o\end{array}$ & 12.34 & 35 & 10.84 & 31 & 12.55 & 29 & 11.14 & 26 \\
\hline$\rho^{2}$ & \multicolumn{2}{|c|}{.54} & \multicolumn{2}{|c|}{.59} & \multicolumn{2}{|c|}{.59} & \multicolumn{2}{|c|}{.69} \\
\hline
\end{tabular}

Note: p: person; r: rater; o: occasion; $\rho^{2}=$ Intra-rater reliability; $b=$ estimated random effect; $\%=$ Percent of total variability.

Table 4 contains the variance component estimates and percentages of total variation for all facets and two-way interaction effects for Model 3 and 4. Model 3 was a $p \times t \times r \times o$ design that included ten variance components. It estimated random effects for persons, raters, tasks, occasions, and their interactions. Among the ten variance components, person and person-by-task effects were the highest. The percentage of variation among the raters was high, indicating a questionable level of intra-rater reliability. Variation among the raters was almost the same as the variation due to the interaction between raters and occasions. This variation also suggests considerable discrepancies between the raters.

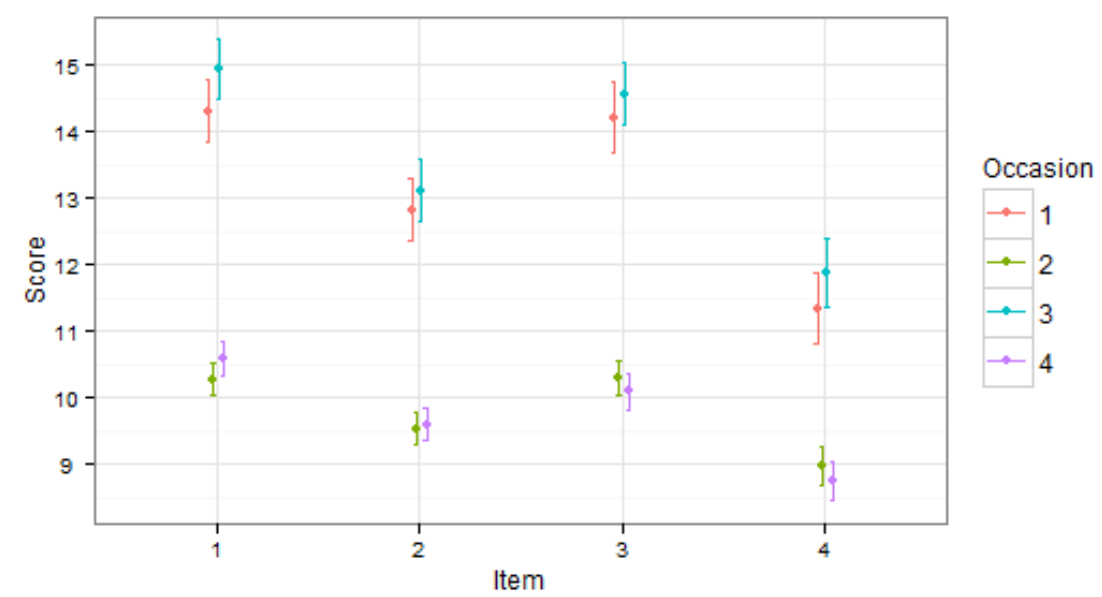

Figure 2. Mean and confidence intervals of the questions across four occasions. 
Table 4

Estimated Random and Fixed Effects for Model 3 and 4.

\begin{tabular}{|c|c|c|c|c|c|}
\hline \multirow{2}{*}{\multicolumn{2}{|c|}{ Effects }} & \multicolumn{2}{|c|}{ Model 3} & \multicolumn{2}{|c|}{ Model 4} \\
\hline & & $b$ & $S E$ & $b$ & $S E$ \\
\hline \multirow[t]{10}{*}{ Random } & $\mathrm{p}$ & 7.58 & 1.36 & 7.58 & 1.35 \\
\hline & $\mathrm{r}$ & 1.81 & 0.74 & 0.35 & 0.48 \\
\hline & $\mathrm{t}$ & 0.91 & 0.56 & 0.91 & 0.49 \\
\hline & o & 4.31 & 0.68 & - & - \\
\hline & $\mathrm{p} \times \mathrm{r}$ & 1.17 & 0.76 & 1.17 & 0.76 \\
\hline & $p \times t$ & 8.54 & 1.39 & 8.54 & 1.39 \\
\hline & $r \times t$ & 0.29 & 0.41 & 0.29 & 0.41 \\
\hline & $\mathrm{r} \times \mathrm{o}$ & 1.96 & 0.78 & 1.91 & 0.62 \\
\hline & rxtxo & 0.58 & 0.54 & 0.54 & 0.54 \\
\hline & $\mathrm{p} \times \mathrm{r} \times \mathrm{t}$ & 0.88 & 0.85 & 0.88 & 0.85 \\
\hline \multirow[t]{2}{*}{ Fixed } & Rubric use & - & - & $-3.63^{*}$ & 0.35 \\
\hline & Experience & - & - & $0.17^{*}$ & 0.03 \\
\hline
\end{tabular}

$\left({ }^{*}\right)$ Significant at $\alpha=.01$

Figure 3 shows estimated random effects and their confidence intervals for each question and rater in Model 3. Question 4 seems to have a smaller random effect on average than the other questions. Although random effects for most raters were similar, there were a few raters (i.e., raters 2, 4, and 9) whose estimated random effects were relatively higher than the rest. This suggests that the scoring of some of the raters differed significantly even after all sources of potential variation were taken into account.

The last model (Model 4) estimated two fixed effects in addition to the variance components in Model 3. However, this model did not include occasion as a variance component because a fixed effect for rubric use was estimated instead of a variance component for four scoring occasions. As expected, the estimated variance components in Model 4 were very similar to the ones from Model 3, except the rater effect, which became smaller in Model 4. The results indicate that both rubric use and teachers' work experience are significant predictors of the variation in the scores. The estimated fixed effect for rubric use was -3.63, meaning that teachers scored 3.63 points less across four items when they used a rubric for scoring the items. This finding is also supported by the higher inter-rater reliability coefficients obtained from the second and fourth occasions where the teachers used a scoring rubric. It implies that teachers tend to score more severely and consistently when a scoring guide is provided. 


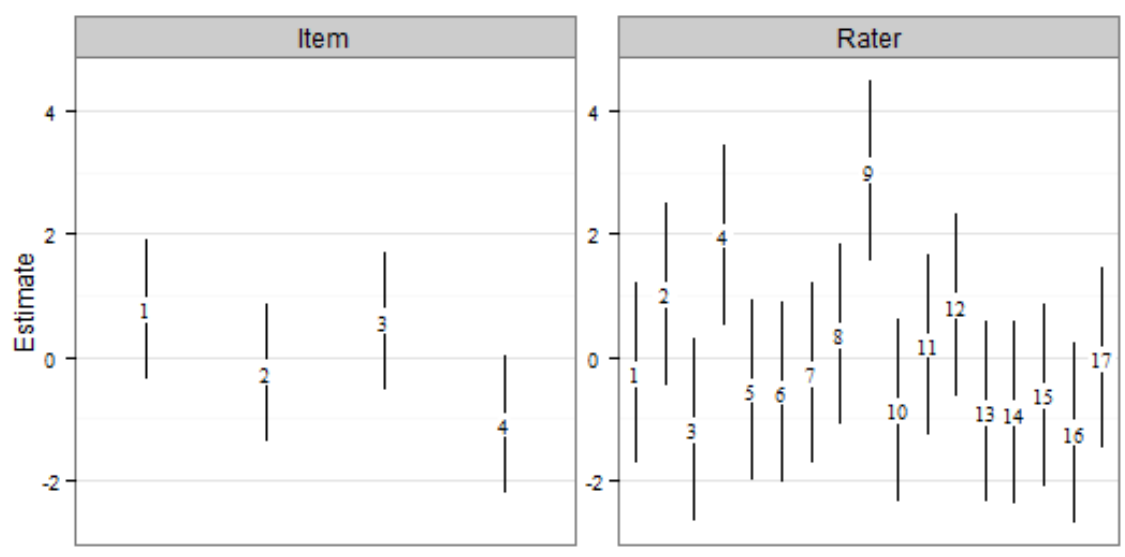

Figure 3. Random effects and confidence interval for questions and raters in Model 3.

Teachers' work experience was positively related to the way the teachers scored the performance tasks. Results indicated that the teachers with more experience assigned higher scores to the items than the teachers with less experience. The reason for this finding might be that the more experienced teachers might not be following the rubric in the same way that the teachers who have recently begun their careers do. Because new teachers are supposed to be more familiar with the nature of performance assessments, they may tend to score more strictly and consistently when grading performance assessments with or without a scoring rubric. It should be noted that although the difference in scores assigned by the experienced teachers and teachers with less experience is obvious, this difference seems to diminish when all of the teachers used a rubric for scoring the items on the performance assessment.

\section{Discussion and Conclusion}

This study utilized a random-effects modeling approach to examine whether rubric use and teachers' work experience influence teachers' scoring behaviors in a performance assessment, with particular attention paid to inter-rater and intra-rater reliabilities and changes in raters' scoring due to rubric use and teaching experience between the occasions. A mathematics assessment that consisted of four questions about graphical comprehension was administered to fifty eighth-grade students. Seventeen mathematics teachers scored the students' responses on four occasions. During the first and third occasions, teachers graded the items without a scoring guide, whereas on the second and last occasions, they scored the responses using a scoring rubric.

The results of this empirical study support the necessity of using a scoring rubric for grading performance assessments. During the first and third occasions, the lack of a scoring guide caused the teachers to establish their own scoring criteria to assess students' performances. Therefore, as an indicator of inconsistency among the 
teachers, the inter-rater reliability coefficient was fairly low. However, when the teachers were given a scoring rubric on the second and last occasions, the consistency among the scores given by the teachers increased. Although the percentage of rater effects seemed to increase on the second and last occasions, the actual amount of variation components for raters became smaller.

The consistency of the scores assigned by the teachers differed across the questions. In the assessment, questions 1 and 3 were less complex compared to questions 2 and 4. Although the same evaluation criteria were applied to the questions, questions 1 and 3 could have been scored more consistently because these graphical questions asked about the relationship between two variables based on a single fact. Therefore, students' responses to them were not expected to vary much. Unlike these questions, questions 2 and 4 focused on the same type of relationship based on two facts, and they were more difficult to interpret. However, intra-rater reliability coefficients indicated that the teachers scored question 4 very consistently but they assigned very different scores for question 1 across the four occasions. The teachers took a lot of points off when they used the rubric to score question 1; they scored the same question more leniently without the rubric. This suggests that the complexity levels of tasks may also influence the way teachers interact with the rubric.

Unlike Myford and Mislevy's (1994) and Meyer's (2000) findings, which suggested that teaching experience only has a negligible effect on raters' scoring behaviors, this study indicated that teaching experience may have a considerable effect on the way teachers approach performance assessments. Based upon the results of this study, it appears that teachers who have more teaching experience tend to score performance tasks more leniently than teachers who do not have long years of teaching experience. Because this was an empirical study, it was not possible to identify whether teaching experience had a positive or negative impact on teachers' scoring behaviors. The differences in the teachers' scoring due to their teaching experience became negligible when all teachers used a scoring rubric. Providing training about the use of scoring rubrics to teachers may also help to reduce the effect of teaching experience on teachers' interaction with scoring rubrics. As Schafer et al. (2001) noted, teachers' understanding of rubrics may change based on additional factors, such as the subject and item types in an assessment. Therefore, in addition to teaching experience, the potential effects of other external factors should also be considered to make the use of rubrics more effective in performance assessments.

This study illustrated an alternative methodology to estimate variance components and the effects of fixed factors within the same analysis. As with generalizability theory models, crossed random-effects models can compute variance components from crossed facets. At the same time, crossed random-effects models are able to estimate fixed effects related to the facets or other components. A big advantage of this modeling approach over generalizability theory is that it allows for the separation of random and fixed effects from each other. In this study, the effects of rubric use and teaching experience were estimated as fixed effects after all sources 
of variation were taken into account. This enabled the researchers to draw additional conclusions about the direct effects of rubric use and teaching experience.

Although the findings of this study enrich the limited knowledge about the effects of rubric use and teaching experience on teachers' scoring behaviors, further research is needed to understand the reasons why these factors are influential. Future research that examines what factors influence teachers' opinions about assigning scores to performance tasks can provide more information about differences in the scoring behaviors of teachers. Researchers should also explore the effects of different types of rubrics, because this study only focused on the use of analytic rubrics for scoring performance tasks. The interaction between teachers and scoring rubrics may also differ based on the type of scoring rubrics.

\section{References}

Ang-Aw, H.T. \& Goh, C.C. (2011). Understanding discrepancies in rater judgment on national-level oral examination tasks. RELC Journal, 42(1), 31-51.

Baird, J., \& Mac, Q. (1999). How should examiner adjustments be calculated? - A discussion paper. AEB Research Report, RC13.

Bates, D. M. (2005). Fitting linear mixed models in R. R News, 5, 27-30.

Bates, D., Maechler, M., \& Bolker, B. (2011). lme4: Linear mixed-effects models using S4 classes. R package version 0.999375-42. http:/ /CRAN.Rproject.org/package=lme4.

Brennan, R. L. (2003). CASMA research report: Coefficients and indices in generalizability theory (Research Report No. 1). Iowa City: The University of Iowa Center for Advanced Studies in Measurement and Assessment.

Brennan, R. L. (2001). Generalizability theory. New York: Springer-Verlag.

Brennan, R. L. (2000). Performance assessments from the perspective of generalizability theory. Applied Psychological Measurement, 24(4), 339-353.

Brualdi, A. (1998). Implementing Performance Assessment in the classroom. Practical Assessment, Research \& Evaluation, 6(2). Retrieved August 29, 2012, from http:/ / PAREonline.net/getvn.asp?v=6\&n=2

Cohen, J. (1960). A coefficient of agreement for nominal scales. Educational and Psychological Measurement, 20, 37-46.

Crocker, L., and Algina, J. (1986). Introduction to classical and modern test theory. Harcourt Brace Jovanovich College Publishers: Philadelphia.

Darling-Hammond, L., \& Snyder, J. (2000). Authentic assessment of teaching in context. Teaching and Teacher Education, 16, 523-545. 
Dochy, F., Gijbels, D., \& Segers, M. (2006). Learning and the emerging new assessment culture. In L. Verschaffel, F. Dochy, M. Boekaerts, \& S. Vosniadou (Eds.), Instructional psychology: Past, present, and future trends (pp. 191-206). Oxford, Amsterdam: Elsevier.

Eckes, T. (2008). Rater types in writing performance assessments: A classification approach to rater variability. Language Testing, 25, 155-185.

Eliasziw, M., Young, S. L., Woodbury, M.G., \& Fryday-Field, K. (1994). Statistical methodology for the concurrent assessment of interrater and intrarater reliability: Using goniometric measurements as an example. Physical Therapy, $74,777-788$.

Farr, R., \& Tone, B. (1998). Le portfolio, au service de l'apprentissage et de l'évaluation. Montréal/Toronto: Chenelière/McGraw-Hill.

Fox, J. (2002). An R and S-PLUS companion to applied regression. Thousand Oaks, CA: Sage.

Friel, S. N., Curcio, F., \& Bright, G. W., (2001). Making sense of graphs: critical factors influencing comprehension and instructional implications. Journal for Research in mathematics Education, 32(2), 124-158.

Hadden, B. L. (1991). Teacher and nonteacher perceptions of second-language communication. Language Learning 41(1): 1-20.

Hafner, J., \& Hafner, P., (2003). Quantitative analysis of the rubric as an assessment tool: An empirical study of student peer-group rating. International Journal of Science Education, 25(12), 1509-1528.

Hamp-Lyons, L. (1991). Scoring procedures for ESL contexts. In L. Hamp-Lyons (Ed.), Assessing second language writing in academic contexts (pp. 241-278). Norwood, NJ: Ablex.

Jolliffe, F. R. (1991). Assessment of the understanding of statistical concepts. In D. Vere-Jones (Ed.), Proceedings of the third international conference on teaching statistics (Vol. 1, pp. 461-466). Voorburg, The Netherlands: International Statistical Institute.

Kulm, G., \& Malcolm, S. (1991). Science assessment in the service of reform. Washington, D. C.: American Association for the Advancement of Science.

Lumley, T (1998). Perceptions of language-trained raters and occupational experts in a test of occupational English language proficiency. English for Specific Purposes, 17(4), 347-67.

Messick, S. (1996). Validity of performance assessments. In G. Phillips (Ed.), Technical issues in large-scale performance assessment (pp. 1-18). Washington, DC: National Center for Education Statistics.

Meyer, L. (2000). Lingering doubt examiners: Results of pilot modeling analyses, summer 2000: AEB Research Report. 
Myford, C.M., \& Mislevy, R. J. (1994) Monitoring and improving a portfolio assessment system. Princeton, NJ: Educational Testing Service.

O'Neil, J. (1992). Putting performance assessment to the test. Educational Leadership, 49, 14-19.

Palm, T. (2008). Performance assessment and authentic assessment: A conceptual analysis of the literature. Practical Assessment, Research \& Evaluation, 13(4), 1-11. Retrieved on September 29, 2012, from http:/ / pareonline.net/pdf/v13n4.pdf

Pinheiro, J. C., \& Bates, D. M. (2000). Mixed-effects models in S and S-PLUS. New York: Springer.

Pinot de Moira, A. (2003). Examiner background and the effect on marking reliability. AQA Research Report, RC218.

R Development Core Team (2012). R: A language and environment for statistical computing. Vienna: R Foundation for Statistical Computing, http://www.Rproject.org.

Raudenbush, S. W., \& Bryk, A. S. (2002). Hierarchical linear models: Applications and data analysis methods. Newbury Park, CA: Sage Publications.

Royal-Dawson, L., \& Baird, J. (2009). Is teaching experience necessary for reliable scoring of extended English questions? Educational Measurement: Issues and Practice, 28(2), 2-8.

Routman, R. (1991). Invitations. Portsmouth, NH: Heinemann.

Schafer, W., Swanson, G., Bene, N., \& Newberry, G. (2001). Effects of teacher knowledge of rubrics on student achievement in four content areas. Applied Measurement in Education, 14(2), 151-170.

Shavelson, R. J., \& Webb, N. M. (2005). Generalizability theory. In Green, J. L., Camilli, G. \& Elmore, P. B. (Eds.), Complementary Methods for Research in Education. (3rd ed.) Washington, DC: AERA.

Shavelson, R. J., \& Webb, N. M. (1991). Generalizability theory: A primer. Newbury Park, CA: Sage.

Shohamy, E., Gordon, C., \& Kramer, R. (1992). The effect of raters' background and training on the reliability of direct writing tests. Modern Language Journal, 76, 1 , 27-33.

Slater, T. F., \& Ryan, J. M. (1993). Laboratory performance assessment. The Physics Teacher, 31(5): 306-309.

Stemler, S. E. (2004). A comparison of consensus, consistency, and measurement approaches to estimating interrater reliability. Practical Assessment, Research $\mathcal{E}$ Evaluation, 9(4). Retrieved on September 11, 2012, from http:/ / PAREonline.net/getvn.asp?v=9\&n=4 
Stuhlmann, J., Daniel, C., Dellinger, A., Denny, R. K., \& Powers, T. (1999). A generalizability study of the effects of training on teachers' abilities to rate children's writing using a rubric. Journal of Reading Psychology, 20, 107-127.

Wainer, H. (1992). Understanding graphs and tables. Educational Researcher, 21(1), 1423.

Ward, D. G. (1986). Factor indeterminacy in generalizability theory. Applied Psychological Measurement, 10, 159-165.

Weigle, S. (1999). Investigating rater/prompt interactions in writing assessment: Quantitative \& qualitative approaches. Assessing Writing, 6(2), 145-178.

West, B. T., Welch, K. B., \& Gallechki, A. T. (2007). Linear mixed models. A practical guide using statistical software. Boca Raton: Chapman \& Hall/CRC.

Wiener, R. B., \& Cohen, J. H. (1997). Literacy portfolios: Using assessment to guide instruction. New Jersey: Prentice Hall.

Wigglesworth, G. (1994). Patterns of rater behaviour in the assessment of an oral interaction test. Australian Review of Applied Linguistics, 17(2), 77-103.

Wood, R. (1968). Objectives in the teaching of mathematics. Educational Research, 10, 83-98.

\section{Çapraz Random Etki Modelleme: Rubrik kullanımı ve Öğretmen deneyiminin Performans Değerleme üzerindeki Etkisinin İncelenmesi}

\section{Özet}

Atıf:

Kan, A., \& Bulut, O. (2014). Crossed random-effect modeling: examining the effects of teacher experience and rubric use in performance assessments. Eurasian Journal of Educational Research, 57, 1-28. doi: dx.doi.org/10.14689/ejer.2014.57.4

\section{Problem Durumu}

Performans değerleme öğrencinin belli bir konuda ne bildiğini ve ne yapabileceğini belirlemek için alternative bir metot olarak görülmektedir. Performans değerlemenin en önemli yetersizliklerinden biri puanlayıcıların puanlamaları arasındaki tutarsızlıklar ve subjektifliktir. Performans değerlemelerin en çok kritik edildiği noktaların başında subjektif puanlama prosedürleri gelmektedir. Performans değerlemelerin etkililiği büyük oranda öğretmenlerin ve rubric puanlama yönergelerinin kalitesi ve koordinasyonuna (etkileşimine) bağlıdır. Öğretmenler ve 
rubric puanlama yönergeleri arasındaki etkileşimi daha iyi anlayabilmek için puanlama prosedürlerini etkileyebilecek potansiyel faktörler dikkatlice belirlenmeli ve incelenmelidir. Bu faktörlerden birisi belki de en önemlisi öğretmenlerin mesleki kıdem ve tecrübeleridir. Bu aşamada deneyimli öğretmenlerin öğretim ve değerlemedeki deneyimlerinden dolayı öğrencilerin performansını daha objektif değerlemeleri beklenebilir. Tabii ki bu az tecrübeye sahip öğretmenlerin tutarsız puanlama yaptıkları anlamına gelmez. Öğretmen (özellikleri) performans değerlemenin etkileşimini daha iyi anlayabilmek için tecrübe vb gibi öğretmenle ilgili faktörleri ve performans değerleme yaparken öğretmen-rubrik puanlama yönergesi etkileşiminin nasıl olduğunu incelemek hayati öneme sahiptir.

\section{Araştırmanın Amacı}

$\mathrm{Bu}$ araştırmanın biri pratik diğeri metodolojik olmak üzere iki amacı vardır. Bu çalışma ile (1) performans değerlemede rubrik puanlama yönergesi kullanımı ve öğretmen deneyiminin puanlama üzerindeki etkisini belirlemek ve (2) varyans bileşenlerini kestirmek ve sabit (fixed) faktörlerin etkisini aynı analiz içinde görebilmek için alternatif bir metodu (crossed random effect ve mixed modeler) örnekleyerek tanıtmak amaçlanmıştır.

\section{Metot}

\section{Araştırma Deseni}

Bu çalışmanın amacı farklı durum ve koşullarda öğretmen deneyiminin ve rubric kullanımının öğretmenlerin öğrenci performans değerlemeleri üzerindeki etkisini incelemektir. $\mathrm{Bu}$ amaç doğrultusunda 8 . Sınıf öğrencilerine bir performans görevi verilmiş ve onların performansları 17 öğretmen tarafından rubric kullanarak ve kullanmadan farklı zamanlarda puanlanmıştır. Toplanan veriler üzerinde öğrenci görev ve öğretmenin ve faktörlerin etkileşimlerinin öğrenci puanlarındaki değişime katkısının ne olduğunu belirlemek üzere Çapraz random etki modelleme yaklaşımı kullanılmıştır. Buna ek olarak rubric kullanımı, deneyim ve değerlemeler arasındaki zaman model içerisinde sabit etki olarak tanımlanmıştır.

\section{Çalışma Grubu ve Verilerin Toplanması}

$\mathrm{Bu}$ çalışma 50 adet 8 . Sınıf öğrencisi ve sekizinci sınıfta derse giren 17 matematik öğretmeni üzerinde yürütülmüştür. Öğretmenlere ait örneklem 1 ile 26 yıl arasında değişen tecrübeye sahip öğretmenlerden oluşmaktadır. Öğretmen, öğrenci ve performans görevi çapraz yüzeyler olarak tanımlanmıştır. Diğer bir deyişle örnekleme giren tüm öğrenciler aynı sorulara cevap vermişler ve tüm öğrencilerden elde edilen cevaplar 17 öğretmenin herbiri tarafından değerlenmiştir. Performans değerlemenin kapsamını grafik yorumlama becerisi oluşturmaktadır. Grafik yorumlama becerisi literature gore çevirme, yorumlama ve sonuç çıkarma (Friel, Bright, \& Curcio, 2001; Wainer, 1992) olmak üzere üç alt boyutta tanımlanarak bu boyutlara gore öğrencilerin grafik yorumlama becerisini değerlemek üzere matematik öğretmenleri ve ölçme ve değerlendirme uzmanı araştırmacılar tarafından performans görevleri yapılandırılmışdır. Performans görevi sayısal verilerin grafiksel gösterimini anlama ve ondan yorum çıkarmaya dönük olarak 
tasarlanmış dört adet açık uçlu sorudan oluşturulmuştur. İlk iki soru bar grafiği diğer iki soru ise çizgi grafiği üzerine kurgulanmıştır.

Öğrenciler performans görevini tamamladıktan sonra 17 öğretmenin her birinden öğrencilerin dört soruya verdikleri cevapları birbirinden bağımsız bir biçimde değerlemeleri istenmiştir. Soruların puan değerleri birbirine eşit ve herbir soru 25 puan değerindedir.Öğretmenler öğrenci cevaplarını 4 farklı zamanda ve durumda değerlemişlerdir. İlk durumda öğretmenlerden öğrenci cevaplarını herhangi bir puanlama anahtarı kullanmadan kendi kriterlerine göre puanlamaları istenmiştir. İlk puanlamadan üç hafta sonra öğrencilerin cevapları aynı öğretmenler tarafından bu sefer ekte sunulan rubrik puanlama yönergesi kullanılarak puananmıştır. Zamanın puanlamalar üzerindeki etkisini görmek üzere bu işlem ilk iki okumadan 10 hafta sonra tekrar edilmiştir. Öğretmenlerin bir önceki puanlamada herbir öğrenciye verdiği puanı hatırlamasını önlemek için öğrenci cevapları her puanlama durumu öncesinde karıştırılmış ve her öğrenciye her puanlamada farklı bir kod numarası verilmiştir. Böylece öğretmenlerin tekrarlı puanlamaları üzerinde oluşabilecek olası önceki puanlamaların etkisini ortadan kaldırmak amaçlanmıştır.

\section{Verilerin Analizi}

Bu çalışmanın deseni birey, görev ve puanlayıcı olmak üzere çapraz üç random yüzeyden oluşmaktadır. Buna ek olarak görev ve puanlayıcılarla çaprazlanmış durum yüzeyi de değişkenliğin diğer bir kaynağı olarak ele alınmıştır. Bu değişkenlik kaynaklarının öğrenci puanları üzerindeki etkisi çapraz random etki (crossed random effect) modeli ile incelenmiştir. Tüm yüzeyler ve etkileşimleri model içerisinde random olarak ele alınmıştır. Random etkilerin yanında öğretmenlerin rubric kullanımı ve deneyimleri gibi iki kestirici de sabit etki olarak ele alınmıştır.

\section{Araştırmanın Bulguları}

Araştırma sonuçları, rubric puanlama yönergesinin kullanılmadığı durumlarda öğretmenlerin kendi puanlama kriterlerini oluşturarak performans görevlerini tutarsız bir şekilde puanladıklarını göstermiştir. Fakat öğretmenler iyi tanımlanmış bir rubrik puanlama yönergesi kullandıklarında puanlayıcılar arası güvenirliğin oldukça yükseldiği gözlenmiştir. Ayrıca tecrübeli öğretmenler ve tecrübesi az olan öğretmenlerin farklı puanlama yaptıkları ve puanlamalarındaki katılık düzeylerinin de farklı olduğu belirlenmiştir.

\section{Araştırmanın Sonuç ve Önerileri}

$\mathrm{Bu}$ araştırmanın sonuçlarına gore; (1) öğretmenlik tecrübesine sahip öğretmenlerin tecrübesi az olan öğretmenlere göre performans görevlerini daha hoşgörülü puanladıkları, (2) Öğretmenlerin deneyimlerine bağlı olarak oluşan puanlama farklılıklarının öğretmenlerin tamamının rubric puanlama yönergesi kullanması durumunda büyük ölçüde ortadan kalkarak önemini yitirdiği belirlenmiştir.

Bu çalışma ayrıca varyans bileşenlerini kestirmek ve sabit (fixed) faktörlerin etkisini aynı analiz içinde görebilmek için alternative bir metodu da örnekleyerek 
tanıtmaktadır. Bu modelin Genellenebilirlik teorisine göre en büyük avantajı, random ve sabit (fixed) etkilerin birbirinden ayrı ele alınmasına olanak vermesidir.

Öğretmen tecrübelerine ek olarak rubrik kullanımına ve performans değerlendirmeye etki edebilecek diğer dışsal faktörlerinde gözönüne alınması ve incelenmesi önerilebilir. Ayrıca bu çalışma öğretmen tecrübeleri ve rubric kullanımının öğretmenlerin puanlamaları üzerindeki etkisine ilişkin olan sınırlı bilgiyi zenginleştirmesine rağmen özellikle bu faktörlerin puanlama üzerinde neden etkili olduğuna ilişkin yeni araştırmalara ihtiyaç vardır. 
Appendix: Scoring Rubric of the Performance Assessment

\begin{tabular}{|c|c|c|c|c|c|}
\hline & \multicolumn{5}{|c|}{ Performance Levels } \\
\hline $\begin{array}{l}\text { Performance } \\
\text { Categories }\end{array}$ & 0 & 1 & 2 & 3 & 4 \\
\hline $\begin{array}{l}\text { Interpretation } \\
\text { of axes }\end{array}$ & $\begin{array}{l}\text { No } \\
\text { attempt } \\
\text { made. }\end{array}$ & $\begin{array}{l}\text { Does not } \\
\text { identify } \\
\text { what each } \\
\text { axis } \\
\text { represents or } \\
\text { mistakes the } \\
\text { meaning of } \\
\text { the axes. }\end{array}$ & $\begin{array}{l}\text { Identifies } \\
\text { only one of } \\
\text { the axes. } \\
\text { Either does } \\
\text { not know the } \\
\text { other axis or } \\
\text { misinterprets } \\
\text { it. }\end{array}$ & $\begin{array}{l}\text { Identifies the } \\
\text { meaning of } \\
\text { each axis but } \\
\text { sometimes } \\
\text { confuses } \\
\text { them. }\end{array}$ & $\begin{array}{l}\text { Is able to } \\
\text { identify what } \\
\text { each axis } \\
\text { represents, } \\
\text { and } \\
\text { interprets } \\
\text { them without } \\
\text { any mistake. }\end{array}$ \\
\hline $\begin{array}{l}\text { Interpretation } \\
\text { of } \\
\text { intersections }\end{array}$ & $\begin{array}{l}\text { No } \\
\text { attempt } \\
\text { made. }\end{array}$ & $\begin{array}{l}\text { Interprets } \\
\text { the crossing } \\
\text { point of } x \\
\text { and } y \\
\text { elements } \\
\text { differently } \\
\text { from the } \\
\text { correct } \\
\text { meaning of } \\
\text { the graph. }\end{array}$ & $\begin{array}{l}\text { Is able to } \\
\text { identify only } \\
\text { a few } \\
\text { crossing } \\
\text { points of } x \\
\text { and y axes, } \\
\text { and } \\
\text { interprets } \\
\text { them } \\
\text { correctly. }\end{array}$ & $\begin{array}{l}\text { Is able to } \\
\text { identify most } \\
\text { of the } \\
\text { crossing } \\
\text { points on the } \\
\text { graph and } \\
\text { interprets } \\
\text { them } \\
\text { correctly. }\end{array}$ & $\begin{array}{l}\text { Is able to } \\
\text { identify all } \\
\text { crossing } \\
\text { points of } x \\
\text { and y axes, } \\
\text { and } \\
\text { interprets } \\
\text { them } \\
\text { correctly. }\end{array}$ \\
\hline Comparisons & $\begin{array}{l}\text { No } \\
\text { attempt } \\
\text { made. }\end{array}$ & $\begin{array}{l}\text { Does not } \\
\text { make any } \\
\text { comparison } \\
\text { based on the } \\
\text { values and } \\
\text { intervals on } \\
\text { the graph or } \\
\text { makes } \\
\text { incorrect } \\
\text { comparisons } \\
\text { that do not } \\
\text { apply to the } \\
\text { graph. }\end{array}$ & $\begin{array}{l}\text { Does not } \\
\text { make a } \\
\text { detailed } \\
\text { comparison } \\
\text { of the values } \\
\text { and intervals } \\
\text { on the graph, } \\
\text { and a few } \\
\text { comparisons } \\
\text { are made } \\
\text { correctly. }\end{array}$ & $\begin{array}{l}\text { Is able to } \\
\text { make most of } \\
\text { the } \\
\text { comparisons } \\
\text { based on the } \\
\text { values } \\
\text { correctly, } \\
\text { and is aware } \\
\text { of the } \\
\text { relationship } \\
\text { (e.g. increase } \\
\text { vs. decrease, } \\
\text { small vs. big) } \\
\text { between two } \\
\text { facts. }\end{array}$ & $\begin{array}{l}\text { Is able to } \\
\text { make } \\
\text { detailed and } \\
\text { meaningful } \\
\text { comparisons } \\
\text { of the values } \\
\text { and intervals } \\
\text { based on the } \\
\text { graph, and } \\
\text { can interpret } \\
\text { the } \\
\text { relationship } \\
\text { between two } \\
\text { facts (e.g. } \\
\text { increase vs. } \\
\text { decrease, } \\
\text { small vs. big) } \\
\text { correctly. }\end{array}$ \\
\hline
\end{tabular}




\begin{tabular}{|l|l|l|l|l|l|}
\hline $\begin{array}{l}\text { Integration of } \\
\text { facts }\end{array}$ & $\begin{array}{l}\text { No } \\
\text { attempt } \\
\text { made. }\end{array}$ & $\begin{array}{l}\text { Is not able to } \\
\text { relate the } \\
\text { facts with the } \\
\text { values on the } \\
\text { graph. } \\
\text { Mentions } \\
\text { totally } \\
\text { irrelevant } \\
\text { facts and } \\
\text { events. }\end{array}$ & $\begin{array}{l}\text { Is able to } \\
\text { identify only } \\
\text { a few data } \\
\text { points but } \\
\text { cannot } \\
\text { explain the } \\
\text { big picture by } \\
\text { looking at the } \\
\text { tendency of } \\
\text { the values on } \\
\text { the graph. }\end{array}$ & $\begin{array}{l}\text { Is able to } \\
\text { identify most } \\
\text { data points } \\
\text { correctly but } \\
\text { cannot fully } \\
\text { integrate the } \\
\text { facts within } \\
\text { the same } \\
\text { context. }\end{array}$ & $\begin{array}{l}\text { Is able to } \\
\text { identify the } \\
\text { relationship } \\
\text { between the } \\
\text { values based } \\
\text { on the trend } \\
\text { on the graph. } \\
\text { about the } \\
\text { Can explain } \\
\text { all facts and } \\
\text { results } \\
\text { consistently } \\
\text { within the }\end{array}$ \\
& & & $\begin{array}{l}\text { fompletely } \\
\text { clear. }\end{array}$ & same context. \\
\end{tabular}


